\title{
Н. А. Троицкая
}

Российский государственный исторический архив Дальнего Востока (Владивосток)

\section{Гражданская война на Дальнем Востоке России в документах Российского государственного исторического архива Дальнего Востока}

Статья посвящена истории комплектования единственного регионального федерального архива документами времен Гражданской войны, предопределившей сложности с выявлением источников. Анализируется степень востребованности этих документов в современных условиях пользователями архивной информации. Дается краткий обзор направлений поиска по всему документальному собранию РГИА ДВ.

Ключевые слова: Гражданская война 1917-1922 гг., РГИА ДВ, документы, проблемы поиска.

\footnotetext{
- раматические события в истории России 1917-1922 гг. на протяжении века находятся в зоне стабильного исследовательского внимания. В полной мере это относится к историографии дальневосточного региона, насчитывающей сотни монографий, статей, диссертаций, мемуарных и краеведческих публикаций ${ }^{1}$. Отдаленность и слабая заселенность тихоокеанской окраины, особенности расстановки социальных сил и незащищенность от вмешательства иностранных государств способствовали тому, что Гражданская война была здесь самой продолжительной ${ }^{2}$. При этом в областях Дальнего Востока «проигрывались» различные варианты политического устройства: от Советов до «Правительства Земской Рати», последнего оплота защитников монархии.

Многолетнее изучение истории Гражданской войны делает актуальным вопрос о перспективах, о пересмотре методологических подходов и углублении понимания, о расширении тематики и введении в оборот новых фактических материалов. В этом плане документальное богатство Российского государственного исто-

1 История Дальнего Востока России. Т. 3. Кн. 1. Дальний Восток России в период революций 1917 года и гражданской войны / отв. ред. Б. И. Мухачев. Владивосток, 2003. С. $7-56$.

2 Ципкин Ю.Н. Белое движение на Дальнем Востоке. 1920-1922 гг. Хабаровск, 1996. C. 5 .
} 
рического архива Дальнего Востока (РГИА ДВ) привлекает внимание пользователей. На фоне продолжающейся дискуссии о «недоступности» архивов необходимо выяснить, что попало на хранение в архив, как и когда.

Время вооруженного гражданского противостояния не самое благоприятное для формирования документальных комплексов. В массовом сознании пепел сожженных беззащитных бумаг убедительно символизировал «прах старого мира». Да и документирование в условиях военных и повстанческих действий не могло быть достойно налажено, а острый дефицит бумаги породил практику ее вторичного использования. В крупных городах Дальнего Востока «старые бумаги» возами отправлялись торговцам на рынок ${ }^{3}$. Получила широкое распространение практика использования «архивных материалов не только до-, но и послереволюционного периода» для изготовления конвертов ${ }^{4}$.

Временные власти пытались принять меры по защите архивов. 26 апреля 1917 г. правительство России издало постановление о сдаче в архивные комиссии предметов, имевших художественное или историко-археологическое значение, в том числе документов. Летом об этом стало известно на Дальнем Востоке ${ }^{5}$, но здесь архивные комиссии не создавались, а документы были сосредоточены в ведомственных и управленческих архивах. Через год аналогичное предписание на места направило Временное Сибирское правительство ${ }^{6}$.

Более основательно к вопросу подошло Российское правительство А. В. Колчака, поставив задачу создания в Сибири Государственной архивной комиссии и подготовки необходимых нормативных актов. 18 июня 1919 г. циркуляром Департамента общих дел Российского правительства, под грифом «срочно», было предписано в губерниях безотлагательно принять меры по охране архивов и приведению их в порядок. К циркуляру прилагался бланк анкеты, содержавший вопросы о состоянии и местонахождении архивов, о составе работников и т. п. Анализ собранных данных должен был помочь «организовать центральные краевые архивы для хранения всех архивных материалов, подлежащих научной разработке» ${ }^{7}$. Таких архивов намечалось создать четыре: в Омске, Томске,

${ }^{3}$ Карев Д.В. К истории становления архивной службы на Дальнем Востоке.1922-1925 гг. // Советские архивы. 1986. № 3. С. 65.

4 Российский государственный исторический архив Дальнего Востока (РГИА ДВ). Ф. Р-38. ОП. 1. Д. 1163. Л. 141.

5 РГИА ДВ. Ф. 1258. Оп. 5. Д. 59. Л. 31.

6 Костанов А.И. Архивы Сибири и Дальнего Востока в 1917-1920 гг. // Отечественные архивы. 2008. № 5. С. 17.

7 РГИА ДВ. Ф. Р-1005. Оп.1. Д. 7. Л. 140. 
Иркутске и Владивостоке. Инициаторы задуманных преобразований были убеждены, что содержание архивных бумаг «имеет большую ценность и для науки, и для практических целей». Результаты этого анкетирования неизвестны. По мнению А. И. Костанова, времени на принятие закона об архивах и осуществление намеченного у Российского правительства не было ${ }^{8}$.

Однако, благодаря усилиям отдельных личностей, значительная часть архивного наследия была спасена от гибели и вывоза за пределы страны. В июне 1920 г. при Государственном Дальневосточном университете было образовано инициативное бюро по учреждению Приморской областной архивной комиссии. Одновременно с решением организационных вопросов оно начало работу по сбору архивных материалов ${ }^{9}$. В июле 1921 г. правительство ДВР приняло закон о признании архивов государственным достоянием. Целенаправленный сбор документов и материалов начала учрежденная 12 сентября 1921 г. Центральная историческая комиссия ДВР по изучению партизанского движения. 20 ноября 1921 г. Временное Приамурское правительство (братьев Меркуловых) утвердило положение о Приморской областной архивной комиссии ${ }^{10}$.

Таким образом, активная позиция людей, входивших в эти бюро и комиссии, позволила сохранить в дальневосточном регионе документальную базу для изучения истории Гражданской войны. Правда, по свидетельству В.П. Голионко, подавляющее количество архивных материалов историко-революционного характера с 1917 г. было неупорядоченным и несистематизированным ${ }^{11}$.

С конца 1922 г. на советский Дальний Восток распространились нормативные акты по архивному делу, принятые Советской властью. В декабре была упразднена архивная комиссия ДВР, а все материалы по истории революционного движения переданы Дальистпарту при Дальбюро РКП(б) ${ }^{12}$. В следующем году началась работа по созданию архивных бюро. Выяснилось, что хранение документов требует значительных финансовых и материальных средств, подготовленных специалистов, способных разобрать документальные залежи, обработать и систематизировать дела. Суровая реальность (неприспособленные сырые помещения, не отапливаемые зимой, с проте-

\footnotetext{
${ }^{8}$ Костанов А.И. Архивы Сибири и Дальнего Востока в 1917-1920 гг... С. 21.

9 Ермакова Э.В. Зарождение архивного дела в Приморье // Известия Российского государственного исторического архива Дальнего Востока: сборник научных трудов / ред. Н. А. Троицкая. Владивосток, 1997. Т. 2. С. 12-17.

10 Владиво-Ниппо (Владивосток). 1921. 20 ноября.

11 РГИА ДВ. Ф. Р-38. Оп. 1. Д. 1163. Л. 166 об.

12 РГИА ДВ. Ф. Р-2422. ОП. 1. Д. 26. Л. 113.
} 
кавшими крышами, отсутствие должной охраны и средств) губила документальное наследие региона. Многие дела до сегодняшнего дня несут на себе следы физического воздействия внешней среды.

Оптимальным решением была признана концентрация архивных фондов в едином крупном центре. В результате возникло Дальневосточное областное (с 1926 г. - краевое) архивное бюро ${ }^{13}$. Перемещение документов в столицу края для создания Дальневосточного архива было, бесспорно, позитивным моментом в судьбе архивного дела в регионе, но не решило проблем. Началась кампания по перевозке в центр страны документов дипломатической части, военного ведомства, членов бывшей царской семьи, контрреволюционных организаций.

Когда выяснилось, что регион не имеет возможности выполнить постановление о создании архивов Октябрьской революции и Красной армии ${ }^{14}$, вывоз ценных документов стал обычной практикой. Согласно секретному сообщению заведующего краевым архивным бюро Леденева секретарю Далькрайисполкома Советов от 19 ноября 1928 г., «весь архматериал, относящийся к периоду партизанского движения ДВ, <..> отправлен в управление Центрархива РСФСР» ${ }^{15}$. При этом, по данным того же комитета, на 1928 г. не была закончена концентрация более 800 архивных фондов, из них примерно 300 относились к пореволюционному периоду до 1922 г. включительно ${ }^{16}$. Президиум Далькрайисполкома, рассматривая план бюро на 19291930 гг., признал его работу неудовлетворительной ${ }^{17}$.

Процесс вывоза документов, зависевший, в том числе от политической ситуации, был долгим и непростым. Об обратном движении дел свидетельствуют учетные документы и обложки со штампами московских архивов. Конечным пунктом стал созданный в 1943 г. в Томске Центральный государственный архив РСФСР Дальнего Востока, ныне - РГИА ДВ. Почти полвека он был оторван от широкого круга исследователей, знающих географию и историю региона. Сибирским архивистам предстояла огромная работа по разбору массива документов. Выражая чувство благодарности поколениям добросовестных сотрудников ЦГА РСФСР ДВ за сохранение дальневосточной истории, нельзя не отметить актуальные болевые точки. Это ошибки и неточности в учетных документах, несоответствие названий дел содержанию, искажение топонимики и фами-

13 РГИА ДВ. Ф. Р-2422. ОП. 1. Д. 463. Л. 52.

14 РГИА ДВ. Ф. Р-38. ОП. 1. Д. 1163. Л. 167.

15 РГИА ДВ. Ф. Р-2413. ОП. 2. Д. 202. Л. 209.

16 РГИА ДВ. Ф. Р-2413. ОП. 4. Д. 143. Л. 11.

17 РГИА ДВ. Ф. Р-2413. Оп. 4. Д. 455. Л. 62. 
лий, искусственное разделение единиц хранения и т. п. Формирование дел из блоков документов, поступавших по весу, необоснованное вмешательство архивистов в состав фондов запечатлены в таблицах фондовых включений и в многократных исправлениях нумерации листов в делах.

Нечеткие представления о правопреемниках привели к объединению в одном фонде документов разных структур или дроблению целого по нескольким фондам. Например, фонды Сахалинского уездного комиссара и управляющего Сахалинским уездом (P-1422 и Р-1412) содержат всего 63 дела. Перед нами архив одной и той же управленческой структуры, так как в 1919 г. Российское правительство приняло решение об изменении названия должности. Документы каждого из четырех фондов Народных собраний (Р-927, Р-467, P-4693 и Р-4694) датируются 1920-1922 гг. Но Приамурское Народное собрание было создано в мае 1921 г., а Временное Народное собрание Дальнего Востока, созванное в июне 1920 г., в декабре признало власть ДВР и объявило себя Приморским областным Народным собранием. Фонд Временного Приамурского правительства, образованного в мае 1921 г., содержит документы с 1918 г. и т. д. Следовательно, для обнаружения и систематизации сохранившейся информации исследователю необходимо проработать документы каждого из этих фондов, что автоматически увеличивает время поиска.

Незнание географии породило искажение топонимики, привело к ошибкам при комплектовании фондов. Некоторые Сахалинские фонды содержат документы Камчатской области и наоборот (P-2338, Р-1428); фонды волостных правлений, таможенных учреждений Приморской области включены в объединенные фонды Амурской области и т. п.

Общепринятая практика разделения фондов на два периода дореволюционный и советский, различающихся наличием или отсутствием буквы «Р» в номере фонда, - также породила проблемы. Смутное пятилетие 1917-1922 гг. в истории дальневосточного региона явно выпадает из понятия «советский». Результаты приблизительных подсчетов показывают, что документы этого периода имеются примерно в $40 \%$ дореволюционных и в $35 \%$ советских фондов. Пользователи нередко «не замечают» документы фондов досоветского периода, а при оформлении ссылок на советские опускают букву «Р» перед номером фонда, что ставит в тупик последователей. Заметный урон количеству и физическому состоянию архивных дел нанесла макулатурная кампания 1940-х годов.

После принятия в 1991 г. постановления о возвращении архива на Дальний Восток двадцать лет решалась проблема с его размеще- 
нием. Основная масса документов находилась в складированном состоянии. Фонды стали доступными только в год 7о-летия РГИА ДВ. В целом судьба архива во многом объясняет сложности выявления документов по истории гражданской войны и их недостаточную вовлеченность в научный оборот. В настоящее время малыми силами специалистов архива начата работа по подготовке путеводителя и усовершенствованию тематического каталога. Погружение в проблемы показало, что финал работы будет нескоро, тем более что с 2016 г. исторический архив стал комплектующимся.

Сегодня в РГИА ДВ практически не работает «обратная связь», так как изучение исследователями истории революции и гражданской войны не может быть названо интенсивным. За прошедшую четверть века в учетных данных зарегистрировано около пяти десятков заявок пользователей, включая любопытствующих дилетантов и начинающих студентов. Среди исследователей отметим докторов исторических наук Н. И. Дубинину (Хабаровск), Б. И. Мухачева (Владивосток), В. И. Шишкина (Новосибирск), Н. А. Шиндялова (Благовещенск), Ю.Н. Ципкина (Хабаровск), кандидатов исторических наук О.В. Авдошкину, Д. А. Ляхова, С. Н. Савченко (все из Хабаровска), В.М. Рынкова (Новосибирск) и др. В тематике преобладают история белого движения, эмиграции, политические предпочтения населения, небольшевистские модели управления и т. п. Меньше, чем в советское время, привлекает история социал-демократического движения, установления Советской власти, история Дальневосточной республики.

Архив опубликовал ряд документов о деятельности в 1917-1922 гг. органов городского самоуправления и таможни, об экономической политике и др. Столетие российских революций было отмечено выпуском сборника документов о деятельности комиссара Временного правительства на Дальнем Востоке ${ }^{18}$. Полученный опыт издания документов из одного фонда (Р-1644) оказался позитивным. Систематизация материалов, составление хроники событий, выявление забытых персоналий помогают определить направления будущих исследований.

Несмотря на разобщенность, неполноту и ошибки в учете сохранившихся материалов, кажущуюся завершенность изучения истории гражданской войны на Дальнем Востоке, документы РГИА ДВ позволяют продолжать активную исследовательскую работу. Отдельными фондами в нем представлены документы органов управ-

18 Дальний Восток России в 1917 году: документы и материалы из фонда Комиссара Временного правительства по делам Дальнего Востока. Владивосток, 2017. 378 с. 
ления Советской власти 1917-1918 гг., Временного правительства автономной Сибири, правительства Алексеевского, Российского правительства А. В. Колчака и его уполномоченного на Дальнем Востоке, Временного правительства - Приморской областной земской управы, Временного Приамурского правительства. Более 100 фондов составляет наследие органов власти ДВР. Правда, количество дел в основной массе этих фондов невелико. Наиболее значительный фонд Р-534 «Приморская областная земская управа» содержит 1524 дела за 1918-1922 гг. Слабо введены в научный оборот материалы фондов комиссаров и управляющих областями и уездами. А в них, например, можно обнаружить такие любопытные документы, как удостоверения с фотографиями на получение пропусков на въезд и выезд из Владивостока в 1919 г. или иски амурских предпринимателей в связи с потерями от деятельности Советской власти в 1918 г.

Смена парадигмы позволяет выделить интересные документы даже во введенных в научный оборот фондах. Фонд Р-725 «Штаб партизанских отрядов Приморья» содержит всего 18 дел за 1919-1922 гг. Преимущественно это документы о снабжении продовольствием, оружием и обмундированием (арматурные списки, требовательные книжки) и т. п. Небольшие обрывки бумаги, с написанным простым карандашом текстом, испачканные и потертые, отражают важные стороны партизанской повседневности. Как и рукописное донесение 1920 г. из отряда Мелехина о получении партизанами оружия в казачьем пос. Новоникольский. Автор его отметил, что «настроение казаков в нашу пользу. Наши хлопцы были великолепно приняты. Кричали казаки „ура“, за здоровье Ленина пили водку» ${ }^{19}$. Сохранилась «Памятка партизана» за 1919 г., своеобразный кодекс чести, предписывавший точное и беспрекословное выполнение приказов, честность и вежливость в отношениях с местным населением, дисциплину и товарищество в отряде ${ }^{20}$.

Деятельность партизан в пограничном Приханкайском районе неизбежно приводила к контактам с таможенниками. По «Временным правилам взыскания пошлин на ввоз и вывоз» (1921 г.), введенным партизанским штабом, все таможенные учреждения района подчинялись цели обслуживания партизанских отрядов ${ }^{21}$. К каждой таможне следовало прикрепить уполномоченного штаба с правом подписи документов. Партизаны отменили запрет на ввоз из-за границы спиртных напитков, сохранили порто-франко для

\footnotetext{
19 РГИА ДВ. Ф. Р-725. Оп.1. Д. 11. Л. 12-12 об.

20 РГИА ДВ. Ф. Р-725. ОП. 2. Д. 22. Л. 9-10.

21 РГИА ДВ. Ф. Р-725. ОП. 1. Д. 3. Л. 67.
} 
простых казаков и крестьян, обложили пошлинами торговцев и жителей городов.

Документы отражают процесс обретения населением гражданского самосознания. Общественный приговор Атамановского поселкового схода об избрании делегатов на съезд партизан (1922 г.) свидетельствует о росте сознательности селян. Предписываемая норма представительства («1 делегат от 100 дворов») лишала поселок, который был в три раза меньше, права выдвигать своего делегата. Несмотря на это казаки приветствовали съезд с пожеланием, «чтобы он вынес свои решения на благо народа к восстановлению государственного порядка мирной трудовой жизни мирным путем» ${ }^{22}$.

Исследователи не уделяют должного внимания фондам ведомств дореволюционного периода: окружных судов, почты и телеграфа, епархий, таможни, народного просвещения и др.

В фонде 534 «Владивостокский окружной суд» сохранились указы и циркуляры Временного правительства, личные дела и именные списки мировых судей периода гражданской войны, переписка с контрразведкой, включающая «Временное положение о военной контрразведке во внутренних округах» 1919 года ${ }^{23}$.

В фонде 1197 «Управление Приамурского почтово-телеграфного округа» имеются документы о деятельности уполномоченного Российского правительства генерала Д. Л. Хорвата, постановления Приморской областной земской управы с автографами руководителей отделов ${ }^{24}$ и др. Богаты документами фонды городских дум и управ с постановлениями о поддержке временных властей, характеристиками общественно-политической жизни и т. п.

В фонде Владивостокского епархиального управления (Ф. 244) сохранились рапорты священнослужителей о гонениях и отказе прихожан от материальной поддержки храмов, циркуляры светских властных структур и др. Например, в одном из дел имеются тексты обращений руководителей правительственных учреждений Владивостока от 1-2 сентября 1918 г. к населению о непризнании власти Временного правительства автономной Сибири и создании Временной коллегии под руководством полковника, профессора-япониста Восточного института В. М. Мендрина ${ }^{25}$. Свои ключи к познанию эпохи хранят недостаточно изученные фонды профсоюзных и кооперативных организаций, съездов промышленников, бирж труда, нотариусов и др.

\footnotetext{
22 РГИА ДВ. Ф. Р-725. ОП. 1. Д. 3. Л. 2.

23 РГИА ДВ. Ф. 534. Оп. 1. Д. 300. Л. 422-423.

24 РГИА ДВ. Ф. 1197. ОП. 1. Д. 701. Л. 20-20 об.

25 РГИА ДВ. Ф. 244. ОП. 1. Д. 1009. Л. 17, 37.
} 
Таким образом, документы РГИА ДВ открывают большие возможности для познания особого и безграничного мира истории конкретных людей, живших, выживавших и боровшихся в смутное время отечественной истории. Архив как лаборатория исследователя требует серьезной продолжительной работы. Хочется верить, что в настоящих условиях развития отечественной исторической науки существует возможность, отказавшись от заданных оценок и мифотворчества, понять и объяснить эпоху в целом. 